\title{
Exchange Rate Volatility and Malawi's Tobacco Exports to The United Kingdom and The United States
}

\author{
Abel Mwanyungwe ${ }^{1}$ \\ ${ }^{1}$ University of Malawi, Malawi \\ Correspondence: Abel Mwanyungwe, University of Malawi, Malawi.
}

Received: September 27, 2016

Accepted: November 11, 2016

Available online: December 7, 2016

doi:10.11114/aef.v4i1.1884

URL: http://dx.doi.org/10.11114/aef.v4i1.1884

\begin{abstract}
The availability and sources of foreign currency in Malawi have become the subject of prominent policy debates in the country in the recent past. Malawi, which traditionally relies on agriculture and foreign aid for foreign currency earnings and balance of payments support, has experienced a shortage of foreign currency. It is against this background that this paper examined the relationship between the responsiveness of Malawi's tobacco exports to the United Kingdom (UK) and the United States of America (US) markets for the period between 1995 and 2011. The objectives of the study were to examine the impact of exchange rate volatility on Malawi's tobacco export earnings to the UK and the US and to determine and compare the volatility coefficients between the two export destinations. Based on the GARCH modelling, the paper found that exchange rate volatility in Malawi varies over time. When there is market disequilibrium in the long run relationship for both markets, there are differences in the rapidity of adjustments relating to the exchange rate volatility coefficient, but these are not significant. For example, the error correction term for tobacco exports to the US is -0.2389 , while the error correction term for tobacco exports to the UK is -0.2341 . This means that there is a relatively faster recovery in the disequilibrium for the tobacco exports to the US than that experienced for the UK market. Given these findings, it is important for researchers and policy makers to pursue appropriate exchange rate policies that will promote exchange rate volatility in Malawi, since the results show that exchange rate volatility has a positive effect on tobacco exports. Hence, the monetary authorities should pursue free and floating exchange rate policies to achieve exchange rate volatility. In addition, authorities should pay particular attention to the collusive behaviour of tobacco buyers, in order to avoid price fixing at the auctions.
\end{abstract}

Keywords: exchange rate, exports, volatility, monetary policies, error correction

\section{Introduction}

Exchange rate volatility refers to the persistent fluctuations of a country's exchange rates over a sustained period of time. The volatility is mainly experienced in regimes of floating exchange rates, although the monetary authorities, under fixed exchange rate policies, can vary the exchange rates to reflect specific policy objectives. Since fluctuations entail that the future rates are unknown to traders and producers, a country may produce and trade less or more depending on the future risks associated with the exchange rate fluctuations (Ozturk and Kalyoncu, 2009). According to Bahmani-Oskooee and Ardalani (2010), flexible exchange rate regimes introduce uncertainties among countries and traders. They argue that, by introducing uncertainty to future prices, exchange rate fluctuations or volatility affect the volume of trade. Because of such uncertainty, traders may choose to trade less. However, some exporters may trade more in order to increase their current income and profit. Therefore, exchange volatility has implications for the volume of international trade and consequently affects the balance of payments. Higher exchange rate volatility leads to higher costs for risk-averse traders and to a reduction in exports.

Agriculture is important to Malawi's economy. The economy is largely dominated by agricultural activities with the sector accounting for about $40 \%$ of the country's total Gross Domestic Product (GDP) in 2010, according to the Reserve Bank of Malawi (RBM) annual economic report. In addition, the agriculture sector accounts for over $80 \%$ of the employed population in Malawi and over $75 \%$ of the total foreign exchange earnings per year. The tobacco sub-sector is, after the government, the second largest employer of formal employees. In addition, tobacco forms the bulk of Malawi's foreign currency earnings, contributing over $50 \%$ of the total export volumes. Total export earnings for the country were US\$945 million in 2012. This means that tobacco constitutes the main "economic engine" in Malawi. 
Persaud and Meade (2009) found that the relationship between Malawi's exports and GDP is asymmetric. The negative impact of falling tobacco export revenues on Malawi's GDP is almost three times greater than the positive impact of an equivalent increase in export earnings (Persaud \& Meade, 2009). Variability in tobacco exports, therefore, is a drag on overall economic growth. Gains in tobacco yields and improvements in marketing efficiency could help buffer Malawi's GDP vulnerability to falling export revenues. Since tobacco is a major foreign exchange earner for the country, its performance has an impact on the value of the exchange rate. If the country earns more foreign currency, it is expected that the exchange rate will appreciate and vice versa.

Malawi's exchange rate policy has evolved over the years since the country gained independence from Britain in early 1964. During the early years of independence, the country's exchange rate was fixed at par with the British Pound Sterling. According to a survey report of the RBM in 2010, the Malawi Kwacha was pegged to the weighted average pound Sterling and the US dollar between 1973 and 1975, and between 1975 and 1984. Although the exchange rate was pegged, the monetary authorities carried out devaluations during the fixed exchange rate regime. The Malawi monetary authorities adopted a floating exchange rate regime in February 1994.

Malawi's over-reliance on tobacco export earnings makes it important to conduct a study to link the sensitivity of such earnings to the changes in the exchange rates over time. This information on the sensitivity of trade flows to exchange rates will offer insight to policy makers to assist them to formulate and develop policies on tobacco exports and exchange rate that will cushion the negative impact of exchange rate volatility on the country's GDP.

Malawi's over-reliance on tobacco export earnings makes it imperative for a study to link the sensitivity of such earnings to the changes in the exchange rates over time. This information on the trade flows sensitivity to exchange rates will offer insight to policy makers to formulate and develop policies on tobacco exports to cushion the negative impact of exchange rate volatility on the country's GDP. Based on this background, the focus of this study is to establish the extent of the sensitivity of Malawi's tobacco export values to the fluctuations in the country's exchange rates for the period between 1995 and 2011. The data used is quarterly data.

The rest of the paper is organised as follows. After the brief introduction, there follows the literature review. In section three, we cover the methodology where the model specification is covered in greater detail. Section four covers the analysis and discussion of the results from the model used. And finally, section five presents the conclusion.

\section{Literature Review}

\subsection{Exchange Rate Volatility and Exports}

Many scholars, including Situ (2015) and Khosa et al (2015) argue that persistent fluctuations of a country's exchange rates over a sustained period of time can send mixed signals to the country's export fortunes. The volatility is mainly experienced in regimes of floating exchange rates, although the monetary authorities, under fixed exchange rate policies, can vary the exchange rates to reflect specific policy objectives.

Situ(2015) reveals that the exchange volatility has a significant impact on exports in developed countries that in export-oriented Least Developed Countries. This means that there is relatively little response in export volumes whenever a country's currency is experiencing turbulent fluctuations. According to Situ (2015), the effects of exchange rate volatility also depends on the different economic characteristics of the exporting countries. While confirming the existence of a long term relationship between exports and exchange rate volatility, Khosa et al., (2015) argue that the variance in the country's currency imposes a negative effect on exports from emerging markets. As such, policy makers in the emerging market economies need to pay attention to the currency movements to sustain export performance.

According to Bahmani-Oskooee and Ardalani (2010), flexible exchange rate regimes introduce uncertainties among countries and traders. They argue that, by introducing uncertainty to future prices, exchange rate fluctuations or volatility affect the volume of trade. Because of such uncertainty, traders may choose to trade less. However, some exporters may trade more in order to increase their current income and profit. Therefore, exchange volatility has implications for the volume of international trade and consequently affects the balance of payments. Higher exchange rate volatility leads to higher costs for risk-averse traders and to a reduction in exports.

The interest in exchange rate volatility or fluctuations and its impact on the flow of international trade can be linked to the debate on the appropriate exchange rate regimes that cropped up in the early 1970s following the collapse of the Bretton Woods (The IMF and the World Bank) institutions (Campa, 2004). The empirical evidence from a number of studies such as Akhtar and Hilton (1994), Gotur (1985), Baak (2004), Kasman and Kasman (2005), Arize et al., (2005) and Chit (2008) revealed that exchange rate volatility has an impact on export and import behaviour in many countries. For Malawi, scholars such as Arize et al., (2000), Silumbu (1995) and Kwalingana et al., (2012) have investigated the impact of the exchange rate volatility and the role of monetary policies on trade. For example, Arize et al., (2000) revealed that the exchange rate volatility has a significant negative impact on the trade flows in Malawi. On the other hand, Silumbu (1995) found that monetary policies, including the use of the exchange rate has yielded poor results in 
influencing positive impact on trade. Silumbu (1995) findings are supported by Kwalingana et al., (2012) who argued that the exchange rate movements have insignificant impact on trade balance position for Malawi.

While studies by Mckenzie (1998) in Australia, De Grauwe (1998) in industrial countries such as Belgium, Canada, and France and Chowdhury (1993) in G-7 countries have been conducted to establish the link or relationship between the exchange rate volatility and the export earnings, there is limited literature on this subject on Malawi. In addition, all these studies use both yearly and quarterly aggregate data on imports and exports of goods and services such as automobiles and agricultural products. Aggregate data, according to Erdem and Nazlioglu (2010), is prone to aggregation bias which could lead to misleading conclusions about the impact of a variable on the subject under consideration. Using disaggregated data, this study is, therefore, an attempt to provide new insights and information to policy makers to formulate appropriate exchange rate and tobacco export policies.

Agriculture is important to Malawi's economy. The economy is largely dominated by agricultural activities with the sector accounting for about 40 per cent of the country's total Gross Domestic Product (GDP), according to the Reserve Bank of Malawi (RBM) annual economic report in 2010. In addition, the agriculture sector accounts for over 80 per cent of the employed population in Malawi and over 75 per cent of the total foreign exchange earnings per year. The tobacco sub-sector is the second largest employer of formal employees next to the government. In addition, tobacco forms the bulk of Malawi's foreign currency earnings, contributing to over 50 percent of the total export volumes. Total export earnings for the country were US\$945 million in 2009. This means tobacco constitutes the main "economic engine" in Malawi. According to Persaud and Meade (2009), variability in tobacco and other export earnings are a drag on the country's overall economic growth and poverty eradication strategies. The major destinations of Malawi's tobacco exports remain Europe, with the UK and the US accounting for a larger share of the country's export volumes.

Persaud and Meade (2009) found that the relationship between Malawi's exports and GDP are asymmetric. The negative impact of falling tobacco export revenues on Malawi's GDP is almost three times greater than the positive impact of an equivalent increase in export earnings (Persaud\& Meade, 2009). Variability in tobacco exports, therefore, is a drag on overall economic growth. Gains in tobacco yields and improvements in marketing efficiency could help buffer Malawi's GDP vulnerability to falling export revenues.

Malawi's exchange rate policy has evolved over the years since the country gained independence from Britain in early 1960. During the early years of independence, the country's exchange rate was fixed at par with the British Pound Sterling. According to a survey report of the Reserve Bank of Malawi (RBM) in 2010, the Malawi Kwacha was pegged to the weighted average Pound Sterling and the US dollar between 1973 and 1975, and between 1975 and 1984. Although the exchange rate was pegged, the monetary authorities carried out devaluations during the fixed exchange rate regime. The Malawi monetary authorities adopted a floating exchange rate regime in February 1994. The decision to float the currency was based on the structural adjustment programme Malawi implemented under the auspices of the IMF and the World Bank. In addition, the change was also influenced by the negative pressures on the balance of payments, the withdrawal of development aid by bilateral and multilateral donors and the demands from regional trading blocs such as the Common Market for Eastern and Southern Africa (COMESA) and Southern Africa Development Community (SADC) to which Malawi is a member (RBM 2010).

\subsection{Tobacco Production and Pricing in Malawi}

Malawi is a landlocked country with a population of about 13 million people, who largely depend on subsistence agriculture for survival. Its economy, with very few mineral deposits, is largely dependent on agriculture. The two major export crops are tobacco which account for over $50 \%$ of the total value of export earnings per year. In addition, agriculture alone accounts for over $34 \%$ of the total GDP, according to a National Statistical Office (NSO) 2010 report.

Table 2.2 is a summary of the contributions of the agricultural sector to the Malawi economy since 2000. The table shows that agriculture's contribution to the country's GDP and its growth rates have been cyclical since 2000. For example, the contribution of the sector to GDP was $39 \%$ in 2000, but increased to $44 \%$ in 2007 and declined to $35 \%$ in 2011 and to $33 \%$ in 2012. The overall performance of agriculture, especially the tobacco sector, declined because of the poor prices that were offered on the auction floors. In addition, the increasing production costs, especially fertiliser and pesticides forced many farmers to cut back on their activities. On the other hand, the agriculture growth rate has also fluctuated from $5.4 \%$ in 2000 to $9 \%$ in 2005. The growth rate went up again to $10 \%$ in 2010 and then fell to $9.8 \%$ in 2012 . 
Table 2.2. Contribution of agriculture (in million US\$) to GDP between 2000-2010

\begin{tabular}{lccc}
\hline Year & Total of agriculture & \% share of agriculture & \% growth (annual) \\
\hline 2000 & 5210 & 39 & 5.4 \\
2001 & 5365 & 39 & 3 \\
2002 & 5310 & 38 & 6 \\
2003 & 5986 & 39 & 9 \\
2004 & 5500 & 38 & 8.4 \\
2005 & 5778 & 41 & 9 \\
2006 & 5119 & 39 & 6 \\
2007 & 6112 & 44 & 12 \\
2008 & 7123 & 39 & 12 \\
2009 & 7459 & 38 & 11 \\
2010 & 7123 & 34 & 10 \\
2011 & 7329 & 35 & 9 \\
2012 & 7411 & 33 & 9.8 \\
\hline
\end{tabular}

Source: Government of Malawi, National Economic Reports (various): 2013

The IMF (2009) regarded Malawi's over-reliance on agricultural exports as rendering it vulnerable to external shocks, such as declining terms of trade and drought. Being a landlocked economy, the country is also being constrained by high transport costs which contribute about 30 percent of the whole import bill. This, according to the IMF (2009), is a serious impediment to trade and general economic growth and to the improvement of the lives of ordinary citizens. Other structural challenges facing the economy include an unreliable transport network, unreliable electricity and water supplies, shortage of skilled manpower and corruption.

Mwasikakata (2003) shows that Malawi's agricultural policies since independence in 1964 have evolved around two sectors. These sectors are the export-oriented sector, which is mainly based on large scale plantations and the food security oriented sector, that is dominated by small scale agricultural structure. While the export-oriented sector has been registering impressive growth and contributed significantly to the overall GDP growth, the smallholder agriculture sector has posted limited growth, because of many structural problems facing the sector. The factors that contributed to the slow growth include limited access to credit, lack of labour absorption capacity because of policy biases regarding land tenure practices and cash crop restriction policies (Mwasikakata 2003).

However, the government adopted a change in policy direction in the late 1990s. The new development strategies focused on the liberalisation of agricultural production and marketing, promotion of smallholder agriculture, privatisation, deregulation and decentralisation of the formal sectors, the adoption of a Medium-Term Expenditure Framework (MTEF) and the institutionalisation of a cash budget system to rationalise government expenditure.

These changes also affected the agriculture sector. The World Bank (1996) report shows that the agriculture sector reforms targeted three major themes. These included the opening up of the burley tobacco market to smallholder farmers. Burley tobacco, the major tobacco crop, was previously dominated by the estate sector alone. Other pillars of the reforms included the promotion of agricultural diversification through increased production and creation of credit facilities. The focus also included the liberalisation of the marketing and pricing of agricultural products.

\subsection{Tobacco Marketing and Pricing}

The Tobacco Control Commission (TCC), a statutory organisation established under an Act of Parliament, is responsible for all the tobacco marketing in Malawi. The commission is also responsible for organising and running the tobacco auction floors in Malawi. The key buyers of Malawi's tobacco are the UK, the US, Netherlands, Switzerland, Germany and recently China. However, of late the market share of Malawi's tobacco export volume is under threat because of the following factors, namely:

(a) An increasingly active anti-smoking lobby in the West, based on the health risks associated with tobacco smoking;

(b) An increase in production costs in Malawi, which is forcing tobacco farmers, especially smallholder producers to exit the market;

(c) A reduction in returns on tobacco farming, forcing farmers to switch to alternative economic activities.

Chilowa (1998) states that both the colonial and post-independence governments left the pricing and marketing activities of agricultural products in the hands of state owned enterprises. For example, the government established the Native Tobacco Board (NTB) in 1926 to control tobacco production. In 1948, the board took over the role of buying tobacco from smallholder farmers and sold the crop on the auction floors. Concerned with the role of food in the 
economy, the government also established two more control bodies (the Maize Control Board and the Cotton Control Board) which were eventually merged with the NTB to form the Agricultural Production and Marketing Board.

However, the total liberalisation of the marketing of agricultural products only occurred in 1987 through an Act of Parliament, when the government removed the quasi-monopoly powers of the Agricultural Development and Marketing Corporation (ADMARC). Prior to the deregulation, ADMARC was responsible for the marketing and establishing of prices for all agricultural products in Malawi.

Poulton (2007) noted that tobacco marketing in Malawi is based on forward-contracts. While the markets are organised on the annually opened auction floors, the buyers come into the buying season with already agreed-upon contracts with multinational cigarette manufacturers. The auction prices are dictated by the market forces of demand and supply. This means prices can fall or rise depending on the prevailing demand and supply conditions.

The tobacco sales on the auction floors are dominated by three major buyers. These are Alliance One, Limbe Leaf and Universal Leaf. However, the Malawi government has recently formed a new company, Malawi Leaf, to offer competition and improve auction prices on the market. There are also smaller private companies, which also buy the leaf on the floors.

While production has sharply increased over the years, there is a worrying downward trend in the prices being offered on the auction floors by the international buyers. Mkwara (2010) says the decline in the tobacco prices in Malawi is in sharp contrast to the international trends, where prices have been on the increase. The declines were mainly felt during the period covering 1998 to 2002 . However, the trend has not changed for the better recently.

FAO (2010) also shows that tobacco prices have sharply declined in Malawi since 1996. The auction price for burley was US\$2.27 per kilogramme in 1996, but the price went down to US\$1.35 per kilogramme in 2000 and then averaged around US\$0.97 per kilogramme in 2010 . The trend is the same for flue-cured tobacco, with the prices falling to around US $\$ 0.76$ per kilogramme in 2010 from US\$1.35 in 2000.

The decline in the tobacco prices is on account of two factors. The major factor has been the substantial increase in production, which has not been matched by a corresponding increase in Malawi's tobacco exports on the international market. The low prices have also been a result of the entry of marginal and smallholder farmers who produce low quality tobacco through lack of technical expertise and limited access to credit (FAO, 2010).

Harrigan (2003) shows that tobacco prices were generally low prior to the 1994 period because of the tobacco restrictions placed on smallholder farmers. The trend was different for estate tobacco farmers who sold their produce on the auction floors. These farmers had access to international buyers (Mkwara, 2010). The state owned ADMARC and the intermediary buyers (IBs) offered very low prices to smallholder farmers.

Mkwara (2010) also shows that prices offered by ADMARC and the IB system were on average about $33 \%$ lower than the international tobacco prices. Although ADMARC prices were lower, Chilowa (1998) argues that the system guaranteed a ready market and certainty to farmers as regards their income flows. Payments for the sales were on spot and farmers were in a position to forecast their sales revenue, based on the pre-determined and fixed prices offered by ADMARC.

However, the liberalisation of the market has seen prices fluctuate over the years. The most affected type of tobacco is burley, which has seen the average prices fall by almost one-third when compared to prices offered between 1996 and 1998. According to Jaffe (2008), the reduction in prices can be explained by a number of factors, including the absence of price support from government, structural imbalances in world supply, reduced demand for burley tobacco and the related build-up of unsold stocks. Jaffe (2008) also points out the uncertainties facing major cigarette manufactures over legal battles relating to health issues.

Although the prices at the auctions are determined by the forces of demand and supply, there are growing concerns that few buyers on the auction floors bring monopoly power. In addition, many smallholder farmers are in urgent need of income and cash and so they are prepared to accept any price offers from the few buyers in the market. Although farmers now are organised under the Tobacco Association of Malawi (TAMA) as a collective body to represent farmers' interests, the organisation has limited influence on the prices offered on the auction floors (FAO, 2010). 


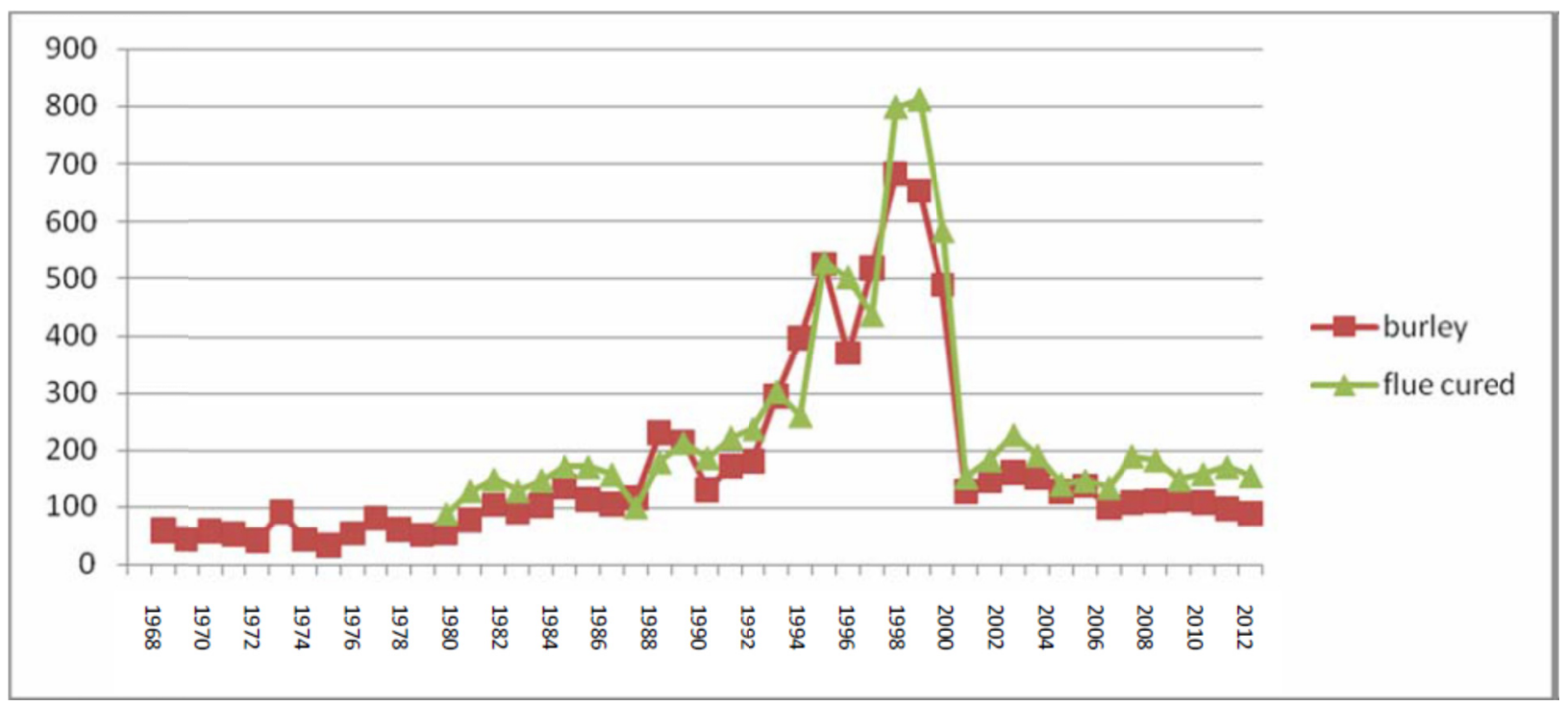

Figure 2.3. Trends in the Prices (in US cents) of Burley and Flue-Cured Tobacco 1968-2012

Source: Tobacco Control Commission (2013)

Figure 2.3 traces the average prices of burley and flue-cured tobacco from 1968 to 2012 . These are the prices tobacco farmers receive on the auction floors from the buyers. They are calculated as averages over the entire year. The table shows that prices for both burley and flue-cured remained below US\$1.0 from 1968 up to the late $1970 \mathrm{~s}$. The prices, however, were between US\$1.0 and US\$3 per kilogramme between 1983 and 1994 . There was a significant increase of prices to above US\$6 per kilogramme between 1994 and 2002. Since 2002, the prices have been on a downward spiral, averaging below US $\$ 1$. The decrease in the prices has been due to over-production and low demand from the traditional tobacco buyers, especially from the Western countries.

\section{Methodology}

This section lays the theoretical foundations of the econometric modelling used to study the relationship between the exchange rate volatility in Malawi and its impact on the tobacco exports to the US and the UK markets. Specifically, the section discusses the data and data sources, the statistical properties of the variables used and the long run and short run modelling for co-integrating relationships. Finally, the section looks at different approaches used in modelling volatility in a variable. The theory behind the unit root tests and statistical properties in economic data is also discussed in this section.

\subsection{Data Used}

The paper uses quarterly time series data from 1995Q1 to 2011Q1. The variables used are the tobacco export values to the US and the UK markets, the average tobacco prices, Malawi's exchange rate against the US dollar and the GDP for the UK and the US. Data on tobacco receipts and average tobacco prices have been sourced from TCC annual reports on sales and exports. Data on exchange rates have been sourced from the Reserve Bank of Malawi, while data on the GDP of the UK and the US has been sourced from the UK Office for National Statistics and US Department of Commerce Bureau of Economic Analysis, respectively.

\subsection{Determining the Unit Root Properties of the Data}

Mello (2005) recommended carrying out unit root tests on time series in order to determine the stationarity and non-stationarity properties of the data. A stationary data time series has its mean and variance that does not vary significantly from its long term trend. This means a non-stationary series will depict randomness and, as such, the series is said to have unit roots.

The presence of non-stationarity in the series leads to spurious regressions. According to Enders (2010), a spurious regression has a high $R^{2}$ and t-statistics that appear to be significant, but the results do not correspond to any economic value or meaning. Various approaches have been put forward to make data stationary in the case of the presence of unit roots in the series. However, the approach used depends on the nature of the trend component in the error term of the variable. Some of the suggested methods are the use of least squares (Alemu et al., 2004), or regressing the variable over time (Gujarati, 2003).

Several tests can be used to test the unit root properties of the data series. One test is the Dickey-Fuller (DF) developed 
by Dickey and Fuller in 1981 (Enders, 2010). The DF test is built on the assumption that the error term is independent and that it is normally distributed. Thus, the DF considers three different regression equations that are used to test the presence of unit roots (Enders, 2010). These equations are thus:

$$
\begin{aligned}
& \Delta y_{t}=\gamma y_{t-1}+\sum_{i=2}^{p} \beta_{i} \Delta y_{t-i+1}+\varepsilon_{t} \\
& \Delta y_{t}=a_{0}+\gamma y_{t-1}+\sum_{i=2}^{p} \beta_{i} \Delta y_{t-i+1}+\varepsilon_{t} \\
& \Delta y_{t}=a_{0}+y_{t-1}+a_{2} t+\sum_{i=2}^{p} \beta_{i} \Delta y_{t-i+1}+\varepsilon_{t}
\end{aligned}
$$

Where $\mu_{t}$ is a white noise error in the equation used and where also

$$
\Delta \gamma_{t-1}=\left(\gamma_{t-1}-\gamma_{t-2}\right), \Delta \gamma_{t-2}=\left(\gamma_{t-2}-\gamma_{t-3}\right) \ldots \ldots
$$

Where $\gamma_{t}$ is the variable at time $t, \gamma_{t-1}$ is the lag value of the variable, $\mathrm{t}$ is the deterministic time trend, and $\Delta \gamma_{t-1}$ is the lagged first difference, which accommodates serial correlation in the error term the random walk. Using OLS, the three equations are run to determine the value of the $\gamma$. The focus of attention in all three equations is the presence of the deterministic elements of $a_{0}$ and $a_{2} t$. The null hypothesis that $\gamma=0$ is first tested. If it turns out to be true, the $n$ variable has a unit root (Enders, 2010).

Because of the criticisms levelled against the DF test surrounding the assumption that the error term is not correlated, Dickey and Fuller extended the test to account for the correlated random walk element. The new test is called the Augmented Dickey-Fuller (ADF) Test. The departure from the original method is that the ADF test adds lagged value of the dependent variable.

The statistical properties of the variables can also be determined using the Kwiatkowski-Phillips-Schmidt-Shin (KPSS) approach. The KPSS test is a simplified version of the ADF test although it has a better predictive power (Leybourne \& McCabe, 1994). The KPSS, however, imposes restrictions on the parameters obtained in the ADF tests. Although it is similar to the ADF test, Leybourne \& McCabe (1994) argued that KPSS accounts for "autocorrelation in a parametric fashion" by including the lagged values of the variable. But scholars such as Bamba \& Reed (2004) and Engle \& Granger (1987) recommended the use of the ADF test to determine the statistical properties of a series. This study uses both the ADF and KPSS tests to determine the presence of unit roots in the series.

\subsection{The Co-Integration and Vector Error Correction Model (VECM)}

Investigations involving the impact of the exchange rate volatility on trade flows involve two methodologies (Chit, 2008). These two models are the long run export demand and the gravity type models. The long run export demand models specify export volumes or values as a function of a number of macroeconomic variables such as GDP, exchange rates, relative prices and the exchange rate volatility. On the other hand, Chit (2008) revealed that the gravity models use geographical factors, such as the market size and the distance among the trading partners, as important variables in influencing trade flows together with economic factors. However, the gravity models have attracted a number of criticisms over their reliability in modelling trade flows. For example, Tenreyro (2007) argued that gravity models suffer from heteroskedasticity problems in the error term. In addition, gravity models do not take into account the zero values in trade and that the models suffer from potential endogenity. As such, the long run export demand models are favoured over the gravity models.

The commonly used long run export demand models include the Ordinary Least Squares (OLS), the Johansen co-integration, the Vector Error Correction Models and the panel co-integration techniques. While scholars such as Bailey \& Taylas (1988), Grube \& Samanta (2003), McKenzie \& Brooks (1997) and Doroodin (1999) have used the 
OLS method to capture the long run relationship, Chit (2008) argued that these approaches lead to spurious regression results and inferences, because of the unrealistic assumptions surrounding their specifications. Chit (2008) favours the use of panel co-integration analysis over both the OLS and Johansen co-integration error correction models. He argued that a panel co-integration analysis, which is a combination of cross-sectional and time series dimensions of the variables, handles simultaneous causality problems associated with economic variables. In addition, a panel co-integration analysis also overcomes the problem of data omissions as it captures both the unobservable trends and policy influences in the data (Chit, 2008).

However, this present study uses the Johansen co-integration and vector error correction techniques despite the limitations of the model pointed out by Chit (2008). This is because the data for this present study are only time series and do not have a cross-sectional dimension. Therefore, a Johansen co-integration and VECM technique is appropriate. Other scholars such as Chowdhury (1993), Arize et al., (2003), Gotur (1985), Asafu-Adjeye (1999) and Bahmani-Oskooee (2002) have also used the co-integration and error correction model with time series data to investigate the impact of the exchange rate volatility on trade flows. Also Mukhtar \& Malik (2010) has also used the VECM techniques. In addition, the VECM has advantages over other time series techniques. As Bini-Smaghi (1991) pointed out, the vector error correction models capture general dynamic relationships among the variables and they do not impose explicit theoretical restrictions on the variables being modelled.

The scope of the co-integration framework used is the Johansen (1988) and the Johansen \& Juselius (1990) maximum likelihood co-integration technique. This technique tests for both the presence of the co-integration relationship among the variables and the number of co-integrating vectors. Hence, a multivariate co-integration equation will be postulated as follows:

$$
Z_{t}=K_{0}+K_{t} \Delta Z_{t-1}+K_{2} \Delta Z_{t-2}+\ldots \ldots+K_{p-1} \Delta Z_{t-p}+\Pi Z_{t-p}+v_{t}
$$

Where $Z_{t}$ is a vector of co-integrating variables to be used. The variables used in this case are the tobacco export

values to the US and the UK, the GDP values for the US and the UK, the interest rates prevailing in Malawi, the exchange rate and the exchange rate volatility. The Trace Statistic and the Maximum Eigenvalue Statistic are used to determine both the presence of co-integration and the number of co-integrating vectors.

Ogundeji (2007) said the Trace Statistic and the Maximum Eigenvalue Statistic use reduced rank regression between the two variables which are $\mathrm{I}(1)$ and $\mathrm{I}(0)$, as long as $n$ eigenvalue $\delta_{1}$ is greater than $\delta_{2}$ and the corresponding eigenvector $v=\left(v_{1}, \ldots v_{\mathrm{n}}\right)$, where the $r$ elements of $v$ are the co-integrating vectors. In addition, the $\delta_{\mathrm{i}}$ is the measure of the strength of correlation between the co-integrating relationships for $\mathrm{i}=1 \ldots . . \mathrm{r}$ (Ogundeji, 2007).

Given this background, a null hypothesis is tested to determine the presence of co-integrating vectors. The null hypothesis is stated as follows:

$$
\mathrm{H}_{0}: \delta_{1}=0 \quad \mathrm{i}=\mathrm{r}+1 \ldots \ldots, \mathrm{n}
$$

The maximal eigenvalue statistic, which is given as $\delta$-max, can then be represented as:

$$
\delta_{\max }=-\operatorname{Tlog}\left(1-\delta_{\mathrm{r}+1}\right) \quad \mathrm{r}=0,1,2, \ldots . \mathrm{n}-1
$$

where $\mathrm{T}$ is representing the number of variables or series and $\left(1-\delta_{\mathrm{r}+1}\right)$ represents the max-eigenvalue estimate.

Additionally, one can find the values of the trace statistic by using the following model:

$$
\delta_{\text {trace }}=T \sum_{i=r+1}^{n} \log (1-\hat{\delta} i) \quad \mathrm{r}=0,1,2, \ldots \ldots \ldots . . . \mathrm{n}-1
$$


This tests the null hypothesis of $r$ co-integrating against the alternative of $r+1$.

Studies by Engle \& Granger (1987) showed that the presence of a co-integrating relationship amongst economic variables implies the presence of a corresponding error correction relationship amongst such variables. This error correction presence suggests that the changes in the dependent variable are a function of the level of disequilibrium in the other variables captured in the co-integrating equation.

Having determined the presence of the co-integration, the study postulates a long run stable equilibrium relationship between tobacco export values with the GDP, average tobacco prices, exchange rate and exchange rate volatility. The specification, as developed by Engle \& Granger (1987), is then used to represent a VECM. The equation to be used is structured as follows:

$$
\begin{aligned}
& \Delta E X P_{t}=\alpha_{0}+\sum_{i=1}^{l} \beta_{1 i} \Delta G D P_{t}+\sum_{i=1}^{m} \phi_{1 i} \Delta A V P R I C E_{t}+\sum_{i=1}^{n} \varphi_{1 i} \Delta \text { EXRATE }_{t}+ \\
& \sum_{i=1}^{p} \lambda_{1 i} \Delta E X V O L A_{t}+\sum_{i=1}^{r} \pi_{t-1} E C T_{r, t-1}+\mu_{t}
\end{aligned}
$$

Where EXP represents both tobacco export values to the US and the UK, GDP is the Gross Domestic Product for the US and the UK, AVPRICE is the average tobacco prices, EXRATE is the exchange rate, EXVOLA refers to the exchange rate volatility captured using the ARCH/GARCH methodology and $E C T$ is the error correction coefficient (term).

Engle \& Granger (1987) showed that if the variables are co-integrated, it means that there is a corresponding error correction representation. This means the changes in the dependent variable are influenced by the level of disequilibrium in the explanatory variables represented in the co-integrating equation. These changes are captured by the error correction term. According to Enders (2010), any deviation from the long run equilibrium is corrected, based on the past values of the co-integrated variables. In addition, the vector error correction model shows how the variables in a co-integrating relationship bounce back towards the long run equilibrium position. However, the coefficients for each variable are the respective responses or elasticities of each variable to deviations from the equilibrium in the short run.

The exchange rate volatility is measured as the conditional variance of the bilateral real exchange rates between the UK and the US on one side and Malawi on the other. The study employs the GARCH statistical method developed by Bollerslev (1986). Since the volatility changes are time dependent and in order to account for the heavy tails of the distribution of exchange rate movements, Kandilov (2008) and Erdem \& Nazlioglu (2010) recommend the use of the $\mathrm{ARCH} / \mathrm{GARCH}$ model, as it performs better in measuring both volatility and uncertainty than the other models.

\subsection{Modelling Exchange Rate Volatility}

Different scholars have used different models to define and measure volatility. For example, Jordaan et al., (2007) showed that volatility can be captured through the standard deviation of the variable or through the coefficient of variation. In addition, the percentage change in the variable and the moving average of the series can also be used to measure volatility. These methods assume that the future values of the series do not depend on its past values. This is known as the unconditional standard deviation of the variance (Jordaan et al., 2007). However, both Moledina et al., (2003) and Just \& Pope (2002) found flaws when using the above mentioned models to measure volatility. These scholars argue that these models do not take into account both the predictable and the unpredictable characteristics of the series. As a result, the methods fail to capture volatility in the series.

Therefore, a number of researchers used the autoregressive conditional heteroskedasticity (ARCH)/generalised autoregressive conditional heteroskedasticity (GARCH) approach to quantify volatility in variables (Worako, Jordaan \& Van Schalkwyk, 2011; Monk, Jordaan \& Grové, 2010; Jordaan et al., 2007; Jooste et al., 2003; and Ghebrechristos, 2004). One of the major advantages of the ARCH/GARCH approach is that it accounts for both the predictable and unpredictable components in the variable measured (Moledina et al., 2009). It also allows new information to influence the volatility in the next period. A detailed description of the procedure for modelling volatility is available in the study done by Moledina et al., (2003) and Jordaan et al., (2007).

The next step towards quantifying the volatility in the exchange rate is to select the appropriate values for $p$ and $q$ in the ARIMA(p,d,q) process (Moledina et al., 2009). The ARIMA process is represented by the following equation (Box \& Jenkins, 1976): 


$$
y_{t}=\alpha_{0}+\sum_{p}^{p \max } \phi_{p} y_{(t-p)}+\sum_{q}^{q \max } \theta_{q} \varepsilon_{(t-q)}+\sum_{n}^{n \max } \eta_{n} D_{t}
$$

After the appropriate ARIMA process is identified, the next step is to test whether or not the series varies over time. The presence of ARCH effect (whether or not volatility varies over time) has to be tested in the conditional variance of:

$$
\begin{gathered}
h^{2}=\operatorname{Var}\left(u_{t} / \Omega_{t-1}\right) \\
h^{2}=\rho_{o}+\rho_{1} u^{2}{ }_{t-1}+\rho_{2} u^{2}{ }_{t-2}+,,, \rho_{q} u^{2}{ }_{t-q}
\end{gathered}
$$

Where $u_{t}^{2}$ is the squared residual in period $t$, and $\rho_{o}, \rho_{l}, \rho_{2}, \rho_{q}$ are the parameters to be estimated.

The ARCH-LM test is performed to test the null hypothesis of no ARCH effect (the series remains constant over time). Failure to reject the null hypothesis means that the volatility remains constant over time and the standard error of the $\operatorname{ARIMA}(\mathrm{p}, \mathrm{d}, \mathrm{q})$ process is used as the measure of volatility. However, the rejection of the null hypothesis means that the volatility changes over time. Varying volatility indicates that the GARCH approach is more appropriate to measure the level of volatility. The univariate $\mathrm{GARCH}(1,1)$ model is presented as:

$$
\sigma_{t}^{2}=\gamma_{0}+\gamma_{1} \varepsilon_{(t-1)}^{2}+\gamma_{2} \sigma_{(t-1)}^{2}
$$

where $\sigma_{t}^{2}$ is the variance of $\varepsilon_{t}$ conditional upon information up to period $t$.

When the GARCH approach is used to measure the volatility in the underlying series the conditional standard deviation is the appropriate measure of volatility. The conditional standard deviation varies over time and includes all new information up to the previous period.

\section{Discussion and Analysis}

This section discusses the results from the various analyses and methodologies for the variables used in this study. Results from the volatility tests exchange rate of Malawi are presented first. The results are from the GARCH model and ARCH-LM tests. The GARCH model and the ARCH-LM tests have been chosen on the basis of their strength in modelling volatility (Jordaan et al., 2007). Secondly, the units tests on all the variables used in the study are presented. The ADF and KPSS unit roots tests have been used to test the properties of the variables, because they have stronger predictive power over the other tests, according to Mello (2005). The section then presents the discussion of the results of the co-integration tests from both the Johansen co-integration test and the residual-based co-integration test. Finally, the section discusses the similarities and differences between the impact of exchange rate volatility on the tobacco exports to the US and the UK markets.

\subsection{Modelling Volatility in the Exchange Rate}

Based on the application of the Box-Jenkins procedure, various ARMA $(\mathrm{p}, \mathrm{q})$ models were tested to determine the best model, on the basis of lower absolute values of the AIC and SBC values relative to the other models' values. The MA(1) model also does not suffer from autocorrelation in the residuals, as both the LM and Correlagram Q-statistics confirm the hypothesis that there is no autocorrelation remaining in the residuals. The Lagrange Multiplier (LM) and the F-tests are used in this study to test the presence of ARCH effects from an ARCH equation. The null hypothesis to be tested is that there are no ARCH effects in the series. The results from the LM tests are presented in Table 3.1

Table 4.1. ARCH-LM Test Results

\begin{tabular}{lll}
\hline Variable & F-statistic & Prob \\
\hline EXRATE & 4.8019 & $0.0003^{*}$ \\
\hline
\end{tabular}

The symbol * represents statistically significant at $1 \%$ level

The tests confirm the rejection of the null hypothesis of no ARCH effect in the series. The rejection of the null hypothesis at the $1 \%$ level of significance means that the exchange rates in Malawi vary over time. This is evidence of volatility in the exchange rates. Hence, the GARCH methodology is adopted. 


\subsubsection{Using GARCH methodology}

Several GARCH(p, q) were tested to find the best fit for the model. Based on the information criteria tools of AIC and SBC, the GARCH $(1,1)$ model was chosen. Compared to the other specifications, the GARCH $(1,1)$ specification had the lowest values of AIC and SBC, hence its choice for modelling the volatility in the exchange rates.

The GARCH approach and tests confirm that conditional standard deviation, which is given by the square root of each of the fitted values of $\sigma^{2}$, varies over time. This can be captured by using the graph below.

The null hypothesis when testing ARCH effects is that there are no ARCH effects in the exchange rates variable. Having rejected the null hypothesis from the table above, it means the variables change over time and, therefore, an appropriate GARCH model should be utilised. One way is to use the univariate GARCH $(1,1)$ method to determine the conditional standard deviation (Jordaan et al., 2007). Having detected the presence of ARCH effects in the exchange rates, an appropriate GARCH process is applied. In this case, it is $\operatorname{GARCH}(1,0)$ model, and the GARCH coefficients were significant.

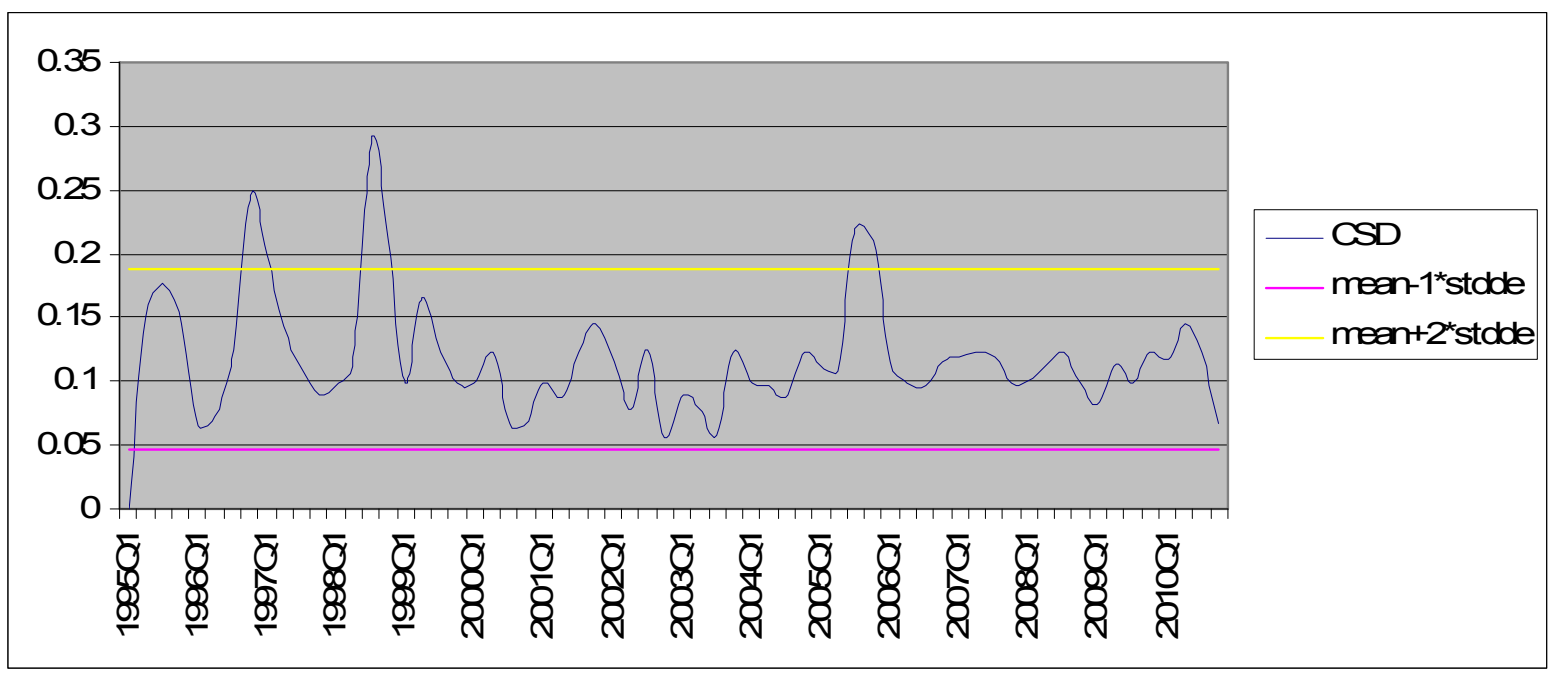

Figure 4.2. Measure of Volatility in the Currency Exchange Rates in Malawi

The presence of spikes in the graph above confirms that there is volatility in Malawi's exchange rates for the period between 1995 and 2011. There are spikes exceeding the two standard deviations boundaries in the graph, especially in the years 1996Q4, 1999Q4 and between 2003Q3 and 2006Q1. This is evidence of upward and downward movement in the conditional standard deviation of the exchange rate in Malawi. Having noted the presence of the varying conditional standard deviation in the exchange rate in Malawi over the years, the next section uses the ADF and KPSS tests to determine the stationarity or otherwise of the variables.

\subsection{Unit Root Test Results}

Mello (2005) states the need to test the unit root properties of the variables to capture the behavioural characteristics of the series in the long term. The commonly used tests are the ADF and the KPSS tests. But Mello (2005) recommends the use of the KPSS test because it has a stronger predictive power. The null hypothesis for the ADF test is that there is a unit root, while the null hypothesis for the KPSS is that the series are stationary. The results are presented in the Table 4.3(a) below:

Table 4.3(a). ADF Unit Root Test $\left(\mathrm{H}_{0}\right.$ : there is unit root)

\begin{tabular}{lllll}
\hline Variable & Test statistic at level & Decision made & $\begin{array}{l}\text { Test statistic at first } \\
\text { difference }\end{array}$ & Decision made \\
\hline LNEXP & $-3.5316^{*}$ & Reject & & Reject \\
LNUSGDP & -3.5332 & Fail to reject & $-3.5332^{*}$ & Reject \\
LNUKGDP & -3.5332 & Fail to reject & $-3.5332^{*}$ & Reject \\
LNAVPRICE & -3.5316 & Fail to reject & $-3.5332^{*}$ & Reject \\
LNRATE & -3.5316 & Fail to reject & $-3.5332^{*}$ & Reject \\
EXVOLA & -3.5349 & Fail to reject & $-3.5365^{*}$ & \\
\hline
\end{tabular}

The symbol * indicates that the series are significantly different from zero at the $1 \%$ level

LNEXP is the log of the tobacco export values to the US and the UK 
LNUSGDP is the log of the GDP of the US

LNUKGDP is the log of the GDP of the UK

LNAVPRICE is the log of the average prices of tobacco in Malawi

LNRATE is the log of the exchange rate

EXVOLA is the exchange rate volatility captured using the ARCH/GARCH procedure

The results from the ADF unit root test show that the LNEXP is stationary at level. However, LNUSGDP, LNUKGDP, LNAVPRICE, LNRATE and EXVOLA are non-stationary at level. However, the series turned out to be stationary after differencing them once. This means LNUSGDP, LNUKGDP, LNAVPRICE, LNRATE and EXVOLA are an I(1) series, while LNEXP is an I $(0)$ series.

Using the KPSS method, the unit root result is presented in Table 4.3(b)

Table 4.3(b). KPSS unit root test (H0: the series are stationary)

\begin{tabular}{lllll}
\hline Variable & Test Statistic at Level & Decision made & $\begin{array}{l}\text { Test Statistics at First } \\
\text { Difference }\end{array}$ & Decision made \\
\hline LNEXP & $0.7390^{*}$ & Fail to reject & Fail to reject \\
LNUSGDP & 0.7390 & Reject & $0.7390^{*}$ & Fail to reject \\
LNUKGDP & 0.73900. & Reject & $0.73900^{*}$ & Fail to reject \\
LNAVPRICE & 0.7390 & Reject & $0.7390^{*}$ & Fail to reject \\
LNRATE & 0.7390 & Reject & $0.7390^{*}$ & \\
EXVOLA & $0.7390^{*}$ & Fail to reject & & \\
\hline
\end{tabular}

The symbol * indicates that the series are significantly different from zero at the $1 \%$ significance level.

Again the KPSS test reveals that the order of integration for all the variables is I(1) except for LNEXP and EXVOLA. This means the order of integration for LNEXP and EXVOLA are I(0) series while LNUSGDP, LNUKGDP, LNAVPRICE and LNRATE are I(1) series.

\subsection{Co-integration and the Vector Error Correction Model}

The procedure in testing for a long term relationship is first to determine the order of integration in the series under discussion. As shown in section 5.3, some variables are $\mathrm{I}(1)$ series while others are $\mathrm{I}(0)$ series. Although Engle \& Granger (1990) argued that co-integration refers to the integration of variables of the same order, it is possible to find equilibrium relationships and co-integration of variables with different orders. These types of co-integration of variables with different orders are known as multi-co-integration (Lee \& Granger, 1990). It is on this basis that the study proceeds with the co-integration analysis. This section employs the technique developed by Johansen (1991) and Johansen \& Juselius (1990) that traces the long run relationship in the following variables: LNEXP, LNUGDP, LNUKGDP, LNAVPRICE, LNRATE and EXVOLA.

The VECM model is used to study the behaviour of non-stationary data that are co-integrated. Co-integration in this case refers to the co-movements of the variables in the long run (Ogundeji, 2011). Engle \& Granger (1987) and Hendry (1986) both agree that a vector error correction model factors out spurious regression effects. Series that are co-integrated adjust to the long run equilibrium whenever there is a shock to a relationship.

\subsection{Johansen Co-integration Test}

The objective of this section is to test whether the variables used in this study are co-integrated. The Johansen approach is used to determine the number of co-integrating equations from the long run relationship involving tobacco exports values, the GDP of the importing countries, the average tobacco prices, exchange rates and exchange rate volatility captured using the GARCH methodology discussed above. The results from the tests are presented in Tables below.

Table 4.4. Johansen co-integration test results for Malawi tobacco exports to the US Unrestricted Co-integration Rank Test (Trace statistic)

\begin{tabular}{cccc}
\hline Hypothesis & Eigenvalue & Trace Statistic & $5 \%$ critical value \\
\hline None* & 0.4236 & 80.4740 & 69.8189 \\
At most 1 & 0.3125 & 46.8625 & 47.8561 \\
At most 2 & 0.2174 & 24.0096 & 29.7971 \\
At most 3 & 0.0876 & 9.0569 & 15.4947 \\
At most 4 & 0.05525 & 3.4672 & 3.8415 \\
\hline
\end{tabular}

The Trace test indicates that there is one co-integrating equation at the $5 \%$ significance level. Therefore, it can be concluded that there is a long term equilibrium relationship between Malawi's tobacco exports to the US, the US GDP, 
the exchange rate, average tobacco prices and the exchange rate volatility.

A residual based test for the tobacco exports to the US was also performed. The results are presented below

Table 4.5. Residual based co-integration test for tobacco exports to the US

\begin{tabular}{lll}
\hline Variable & Coefficient & Probability \\
\hline Residuals & $-3.5402 *$ & 0.0000 \\
\hline significant at the 1\% level & &
\end{tabular}

Since the residuals are stationary at level, it is a further confirmation that there exists a long run equilibrium relationship between Malawi's tobacco exports to the US, the USGDP, the average prices, exchange rates and the exchange rate volatility. This means that the variables are co-integrated.

Table 4.6. Johansen co-integration test results for Malawi tobacco exports to the UK Unrestricted Co-integration Rank Test (Trace statistic)

\begin{tabular}{cccc}
\hline Hypothesis & Eigenvalue & Trace Statistic & $5 \%$ critical value \\
\hline None* $^{*}$ & 0.4041 & 81.0796 & 69.8189 \\
At most $1^{*}$ & 0.3037 & 48.4638 & 47.8561 \\
At most 2 & 0.2252 & 25.6586 & 29.7971 \\
At most 3 & 0.0947 & 9.5860 & 15.4947 \\
At most 4 & 0.0513 & 3.3201 & 3.8415 \\
\hline
\end{tabular}

The Trace test indicates that there are two co-integrating equations at the $5 \%$ significance level. Therefore, it can be concluded that that there is a long term equilibrium relationship between Malawi's tobacco exports to the UK, the UK GDP, the exchange rate, average tobacco prices and the exchange rate volatility.

A residual based test was also used in addition to the Johansen approach to determine the presence of co-integration among the variables. This was done by using the residuals obtained from a long run relationship among the variables. These residuals are then tested for stationarity. The results are presented in Table 5.4(d).

Table 4.7. Residual based co-integration test for tobacco exports to the UK

\begin{tabular}{lll}
\hline Variable & Coefficient & Probability \\
\hline Residuals & $-3.5402 *$ & 0.0000 \\
\hline significant at the $1 \%$ level & &
\end{tabular}

The results from the ADF stationarity test confirm that the residuals from the long equilibrium equations are stationary at the $1 \%$ significance level. This is further confirmation that a long run relationship exists among the variables under study. The section below reports the results of the long run models for both tobacco export values to the UK with other variables such as LNGDP, LNPRICE, LNRATE and the exchange rate volatility.

\subsection{The Long Run Tobacco Response Function Showing Elasticities for the US Market}

Following the Johansen procedure to estimate co-integration, a specification test to determine the lag length of the short and long run model was carried out through a normal VAR procedure. The information criteria tools used in determining the appropriate lag length are the Akaike Information Criterion (AIC), Schwarz Information Criterion (SC), the final prediction error (FPE) and Hannan-Quinn information criterion (H-Q). The results of the lag test are presented in the Table below.

Table 4.8. Lag length structure selection for Johansen procedure for the US market

\begin{tabular}{ccccc}
\hline Lag & LR & FPE & AIC & SC \\
\hline 0 & NA & $5.47 \mathrm{e}-08$ & -2.5327 & -2.3567 \\
1 & 521.0861 & $6.88 \mathrm{e}-12$ & -11.5171 & $-10.4607^{*}$ \\
2 & 50.4369 & $5.72 \mathrm{e}-12$ & -11.7204 & -9.7837 \\
3 & $27.3313^{*}$ & $7.41 \mathrm{e}-12^{*}$ & $-11.5086^{*}$ & -8.6916 \\
4 & 48.5206 & $5.29 \mathrm{e}-12$ & -11.9380 & -8.2406 \\
\hline
\end{tabular}

The Lag Order Selection Criteria results show that the VAR model selects lags between 1 and 4. For example, the SC settles for 1 lag while the AIC, LR and FPE choose 3 lags. Using the majority rule, both the long run and the short run models will use 3 lags as selected by the LR, FPE and AIC. The results from the VECM are presented and discussed in the sections below that presents the long run relationship for the US tobacco market. 
Table 4.9. The long run tobacco response function showing elasticities for the US market

\begin{tabular}{lll}
\hline Variable & Coefficient & t-Statistic \\
\hline LNUSGDP(-1) & -9.8462 & $-3.0713^{*}$ \\
LNAVPRICE(-1) & 1.4375 & -1.4375 \\
LNRATE(-1) & 2.3448 & $3.3448^{*}$ \\
LNVOLA(-1) & 23.5810 & $5.5598^{*}$ \\
\hline
\end{tabular}

* significant at the $1 \%$ level

The long run elasticity for the US GDP, which can be used as a proxy for foreign income for lag 1 is relatively high at -9.85 and statistically significant. Arize et al., (2000) offered three explanations for higher income elasticity associated with foreign incomes. First, he noted that large income elasticity in most export-demand relationships are consistent with empirical evidence. Arize et al., (2000) also argued that the high income elasticity is evidence of the speed of adaptation of the exports to local tastes in importing countries.

The income elasticity for tobacco exports, although significantly high and statistically significant, is negative. This is contrary to a priori reasoning, which suggests that demand and income have a positive relationship. However, Nsiku \& Botha (2007) provide explanations for this negative relationship. First, the anti-smoking lobby and campaigns in the developed countries significantly affected Malawi's tobacco exports to most countries. Secondly, allegations about the use of child labour in most tobacco estates in Malawi also forced many tobacco buyers, including the US, to scale down their orders from Malawi (Nsiku \& Botha, 2007).

The price elasticity at 1.4375 is statistically insignificant at lag 1 . It means that it is elastic. It, however, has a positive sign. There are various explanations for the insignificant price elasticities for exports from LDCs in general and tobacco exports from Malawi. Arize et al., (2000) said price elasticities are insignificant because they reflect the use of unit value indexes calculated from aggregated variables. In addition, LDC countries differentiate their export products by focusing on non-price factors such as delivery specifications, product design and aggressive marketing. Therefore, prices become insignificant influences in the export-demand function (Arize et al., 2000). For Malawi tobacco exports, Mkwara (2010) and Nsiku \& Botha (2007) argued that tobacco prices in Malawi have insignificant influences on farmers and exporters' decision making because of the nature of the marketing system in Malawi. The tobacco auction markets are dominated by a few monopolistic buyers who collude in setting up prices at the expense of tobacco farmers (Nsiku \& Botha, 2007).

The elasticity for exchange rate volatility (23.5810) is positive for lag 1 . The coefficient is also statistically significant. The positive value suggests that Malawi's tobacco producers and exporters react positively to exchange rate volatility by increasing their production and exports to the US. The positive linkage between exchange rate volatility and export revenue is supported by a number of scholars such as Arize et al., (2000), McKenzie (2002), Kasman \& Kasman (2005) and Bailey \& Tavlas (1998). These scholars argue that the fear of current losses as a result of exchange rate volatility can spur an economic agent to produce more as an insurance cover for future earnings and income to smooth over the income during the entire period. For example, McKenzie (2002) contends that most economic agents base their decisions on the worst scenario basis. Thus, the fear of income loss now can motivate an economic agent to produce more to cover up for the expected decline in current incomes.

\subsection{The Long Run Tobacco Response Function Showing Elasticities for the UK}

Following the Johansen procedure to estimate co-integration, a specification test to determine the lag length of the short and long run model was carried out through a normal VAR procedure. As for the response function for the US, the information criteria tools used in determining the appropriate lag length are the AIC, the SC, the FPE and the H-Q information criterion. The results of the lag test are presented in Table below.

Table 4.10. Lag length structure selection for Johansen procedure for the UK market

\begin{tabular}{lllll}
\hline Lag & LR & FPE & AIC & SC \\
\hline 0 & NA & $7.64 \mathrm{e}-05$ & 4.7098 & 4.8785 \\
1 & 697.8672 & $9.96 \mathrm{e}-10^{*}$ & $6.5411^{*}$ & $-5.5292^{*}$ \\
2 & $40.5996^{*}$ & $1.03 \mathrm{e}-09$ & -6.5259 & -4.6706 \\
3 & 25.2964 & $1.37 \mathrm{e}-09$ & -6.2717 & -3.5731 \\
4 & 23.1495 & $1.88 \mathrm{e}-09$ & -6.0288 & -2.4869 \\
\hline
\end{tabular}

The Lag Order Selection Criteria results show that the VAR model selects lags between 1 and 2. For example, the SC, AIC, FPE and HQ settle for 1 lag while LR selects 2 lags. Both lags will be tested to establish the appropriateness of the model to be used. Although the majority of the tests settle for 1, the model suffers from the problem of multi-co-linearity in the residuals. Hence the choice of 2 lags. The results from the models are presented and discussed in the sections below. 
Table 4.11. The results from the models are presented and discussed in the sections below

\begin{tabular}{lll}
\hline Variable & Coefficient & T-statistics \\
\hline LNUKGDP(-1) & 22.8193 & 1.1028 \\
LNAVPRICE(-1) & -1.1753 & -0.7753 \\
LNRATE(-1) & -0.7115 & -0.1671 \\
LNVOLA(-1) & 0.1770 & 0.2840 \\
Constant & 121.7027 & $2.3075^{*}$ \\
\hline
\end{tabular}

* represents statistically significant at the $5 \%$ level

The long run elasticity for the UK GDP on tobacco export values from Malawi is positive. The coefficient (22.8193) is, however, insignificant. The meaning of the positive sign is that an increase in the GDP (which can be used as a proxy for income for UK citizens) will induce an increase in demand for a product. In this case, demand for Malawi tobacco increases as the UK GDP increases. The coefficient is greater than 1, meaning that tobacco exports are income elastic.

The price elasticity for tobacco exports is insignificant, but with an expected negative sign. The statistically insignificant price elasticitiy is as expected according to Arize et al., (2000), Mkwara (2010) and Nsiku \& Botha (2007). The insignificant impact of the price elasticity stems from the fact that tobacco buyers on the auction floors collude in setting up prices, hence prices become irrelevant in influencing the direction of demand or supply.

The exchange rate volatility elasticity is statistically insignificant. This means the exchange rate volatility plays a very insignificant role in influencing tobacco exporters' behaviour in Malawi. The insignificant coefficients for the exchange rate volatility confirm the findings of Kwalingana et al., (2012), who argued that the exchange rate movements in Malawi do not influence Malawi's exports, because the country is a price taker on the international market. They believed that exchange rate movements do not significantly influence demand through price incentives that can be associated with a currency movement.

\subsection{The Short Run Response Model for Tobacco Exports}

This section estimates the short run elasticities using the VECM. The VECM assumes that there is co-movement in non-stationary variables that are co-integrated. If the variables are co-integrated, it means that their short run disequilibrium in cases of shocks or disturbances is restored back to its long term equilibrium trend. The general VECM is represented as follows:

$$
\Delta X_{t}=k+\sum_{w} \lambda_{w} \Delta X_{t-n}+\delta\left(X_{t-1}-\sum_{j} \gamma_{j} \pi_{t-n}\right)+\beta T+\mu_{t}
$$

Although the coefficients of the other variables are important, the focus of this study is on the impact and relationship between the tobacco export values to the US and the UK and the exchange rate volatility.

The methodology used is the "general-to-specific paradigm" as suggested by Hendry (1987). The VAR lag selection criteria chose three lags for the US model and two lags for the UK model. The autocorrelation and normality tests for the residuals also confirm that the lag criteria meet the tests of appropriateness of the VAR model chosen. The results are presented in the tables below for analysis and discussion.

Table 4.12. Short run elasticities for tobacco exports to the US

\begin{tabular}{lll}
\hline Variable & Coefficient & t-Statistic \\
\hline$\Delta$ LNUSGDP & 0.0017 & 1.4940 \\
$\Delta$ LNUSGDP(-1) & 4.6299 & 0.2145 \\
$\Delta$ LNUSGDP(-2) & 0.3 .8148 & 0.1934 \\
$\Delta$ LNAVPRICE & 0.02519 & 0.8689 \\
$\Delta$ LNAVPRICE(-1) & -1.3733 & $-1.7236^{* *}$ \\
$\Delta$ LNAVPRICE(-2) & -0.6228 & -0.7264 \\
$\Delta$ LNRATE & 0.0102 & 0.7163 \\
$\Delta$ LNRATE(-1) & 1.5023 & 0.8555 \\
$\Delta$ LNRATE(-2) & -1.2787 & -0.7041 \\
$\Delta$ LNVOLA & -0.0316 & $-3.7409^{*}$ \\
$\Delta$ LNVOLA(-1) & 2.0898 & 0.6778 \\
$\Delta$ LNVOLA(-2) & 7.3634 & $2.82 .96^{*}$ \\
ECT & -0.2389 & $-2.4537^{*}$ \\
\hline
\end{tabular}

$*$ and ${ }^{* *}$ represent significance at the $1 \%$ and $5 \%$ level, respectively

The error correction term in the short run relationship for tobacco exports to the US is negative and statistically 
significant at the $1 \%$ level. Olubode-Awosola et al., (2006) argued that a negative and significant error term is a confirmation of the existence of a long run equilibrium relationship among the variables being investigated. The error term also represents the speed of adjustment of the tobacco export values (the dependent variable) in the short run back to the long run equilibrium position. In the case of tobacco exports to the US, the error term is -0.2389 . This means that about 24 per cent of the proportion of the disequilibrium experienced in tobacco exports in the previous quarter of the year is restored back to the long run equilibrium position within a year after the disturbance or shock.

Using the procedure of parameter space dimension in a parsimonious specification, (Arize et al., 2000), statistically insignificant coefficients are eliminated from the model to allow for analysis on statistically significant variables. The results from Table 5.7.1 show that the average tobacco price and the exchange rate volatility are significant factors influencing tobacco export values to the US market. Price is significant at lag 1, while exchange rate volatility is significant at lag zero.

The elasticity of the exchange rate volatility is negative (-0.0316) and statistically significant at the $5 \%$ significance level. Therefore, there is a negative relationship between Malawi's tobacco exports to the US and the exchange rate volatility. This means Malawi's tobacco producers and exporters react negatively to exchange rate volatility by reducing their production and exports to the US in the short run. The negative linkage between exchange rate volatility and export revenue is supported by a number of scholars such as Arize et al., (2000), McKenzie (2002), Kasman \& Kasman (2005) and Bailey \& Tavlas (1998). These scholars argue that the fear of current losses as a result of exchange rate volatility can persuade economic agents to produce less.

The elasticity of the exchange rate (at lag zero) is positive and statistically insignificant, while the price elasticity of tobacco exports (at lag 1) is negative and statistically significant at the $5 \%$ level. This is also according to a priori reasoning. An increase in the price of tobacco will lead to a reduction in the demand for the product in the short run, hence a negative coefficient in the short run.

The short-run VECM model for the UK market is presented in Table below.

Table 4.13. Short run elasticities for tobacco exports to the UK

\begin{tabular}{lll}
\hline Variable & Coefficient & t-Statistic \\
\hline$\Delta$ LNUKGDP & 19.7252 & 1.5647 \\
$\Delta$ LNUKGDP(-1) & -39.3640 & $-3.2466^{*}$ \\
$\Delta$ LNUKGDP(-2) & -4.7048 & -0.4099 \\
$\Delta$ LNRATE & -0.0349 & -0.0226 \\
$\Delta$ LNRATE(-1) & 1.5132 & 0.8681 \\
$\Delta$ LNRATE(-2) & -0.2999 & -0.1862 \\
$\Delta$ LNAVPRICE & -0.1547 & -0.2196 \\
$\Delta$ LNAVPRICE(-1) & -1.9837 & $-2.5542^{*}$ \\
$\Delta$ LNAVPRICE(-2) & 1.1657 & 1.5198 \\
$\Delta$ VOLA & 0.4907 & 1.6120 \\
$\Delta$ VOLA(-1) & -0.0736 & -0.2518 \\
$\Delta$ VOLA(-2) & 0.3822 & 1.2798 \\
ECT & -0.2341 & $-2.6087^{*}$ \\
\hline
\end{tabular}

$*$ represents statistically significant at the $1 \%$ level

The error correction term in the short run relationship for tobacco exports to the UK is negative and statistically significant at the $1 \%$ level. The value of the error tem is -0.2341 . This means that about $23 \%$ of the disequilibrium experienced in tobacco exports in the previous year is restored back to the long run equilibrium position within a year after the disturbance or shock.

The elasticity of the exchange rate volatility is positive except for lag 1, which is negative. However, the elasticities are not statistically significant. This means the exchange rate volatility plays an insignificant role in influencing tobacco exporters' behaviour in Malawi. This confirms the findings of Mkwara (2010) and Kwalingana et al., (2012) that the tobacco pricing and marketing structure in Malawi is characterised by collusive behaviour, such that market forces play very insignificant roles in influencing the direction of production and exports. In addition, they argue that internal factors such as the country's GDP and structural factors are more important drivers of export growth in Malawi.

The price elasticity of tobacco exports is statistically significant at lag one. It is also negative (-1.9837) as expected. This means that an increase in tobacco prices leads to a decrease in Malawi's tobacco exports to the UK. Also the income elasticity of tobacco is statistically significant at lag 1, but it is negative. This is against a priori expectations. An increase in income is expected to lead to an increase in demand. However, it is noted that the income elasticity is positive, but insignificant in all the other lags of the model. The insignificant influence is also seen in the elasticity of the exchange rate. 
Differences and similarities between the US and the UK as export destinations

The general observations from aggregate data on exports postulates either a positive or negative relationship between the export volumes/revenue and the country's exchange rate volatility. However, McKenzie (1998) showed that the type of export product and the destination of the export product influence the type of response to the exchange rate volatility. Having disaggregated Malawi's export basket, it is important to highlight the differences in reactions of specific export commodities to specific export destinations. This is a departure from the investigations of Arize et al., (2000) on the impact of the exchange rate volatility on export flows for 13 LDC countries, which included Malawi.

The impact of the exchange rate volatility on tobacco exports to the US market is positive for lag 1 and lag 2 in the short run. However, the impact is statistically significant at lag 2 only while it is insignificant at lag 1 . For the UK market, the impact of the exchange rate volatility is negative at lag 1, but positive at lag 2 in the short run. Also, the coefficient is statistically significant at lag 2 but not at lag 1 . In the long run, the exchange rate volatility is positive and statistically significant for the US market at lag 1 . Although the exchange rate volatility coefficient is also positive at lag 1 for the UK market, the impact is insignificant. This supports the findings of McKenzie (1998) that different markets depict different reactions to exchange rate volatility.

There are also insignificant differences in the speed of adjustments when there is market disequilibrium in the long run relationship for both products and markets. For example, the error correction term for tobacco exports to the US is -0.2389 , while the error correction term for tobacco exports to the UK is -0.2341 . This means that there is a relatively quicker recovery in the short run disequilibrium for the tobacco exports to the US compared to that experienced for the UK market.

\section{Conclusion}

The study has revealed that the impact of the exchange rate volatility on tobacco exports to the US market is positive for lag 1 and lag 2 in the short run. However, the impact is statistically significant at lag 2 only while it is insignificant at lag 1. Similarly, the long run impact of the exchange rate volatility on Malawi tobacco exports to the US is positive and significant at lag 1. For the UK market, the impact of the exchange rate volatility is negative at lag 1 , but positive at lag 2 in the short run. Also, the coefficient is statistically significant at lag 2, but not at lag 1 . In the long run the exchange rate volatility coefficient is also positive at lag 1 for the UK market, but its impact is not significant. This is evidence of McKenzie's (1998) findings that different markets depict different reactions to exchange rate volatility.

There are also insignificant differences in the speed of adjustments when there is market disequilibrium in the long run relationship for both products and markets. For example, the error correction term for tobacco exports to the US is -0.2389 , while the error correction term for tobacco exports to the UK is -0.2341 . This means that there is a relatively quicker recovery in the short run disequilibrium for the tobacco exports to the US than that experienced for the UK market. The insignificance of the in the differences in the speed of adjustment could also be evidence of Mkwara (2010) findings that the existence of price fixing in the tobacco market in Malawi.

The exchange rate has remained one of the major determinants of the economic development for countries over the years. Therefore, the management of the exchange rate policy is central to policy makers. As studies have shown, the movements in the country's exchange rate influences trade, inflation, interest rates and the overall economic growth and development. Given the findings from this study, the impact of the exchange rate volatility depends on the market destination of Malawi's tobacco exports. Therefore, it is important for policy makers to pay particular attention to the exchange rate of the Malawi kwacha in order to align it with export objectives.

Although the paper has provided evidence on the impact of the exchange rate volatility on tobacco exports to the US and UK markets, there are still gaps that need to be exploited. For example, there are still gaps associated with the causes of the exchange rate volatility in Malawi. Studies to investigate the real causes of the exchange rate volatility in Malawi would be relevant to policy makers involved in export promotions. Furthermore, studies in the differences in the market structures and conditions for the US and UK destinations for Malawi tobacco will also be relevant.

\section{References}

Akhtar, M., \& Hilton, R. (1994). The effect of exchange rate uncertainty on German and US trade. Federal Reserve Bank of New York Quarterly Review, 7-16.

Alemu, G., Oosthuizen, L., \& Van Schalkwyk, H. (2004). The effect of persistence of major changes in economic policies on the long-term performance (trend) of Ethiopian agriculture. Quarterly Journal of International Agriculture 45(3), 210-225.

Arize, A., Osang, T., \& Slottje, D. (2000). Exchange rate volatility and foreign trade: Evidence from thirteen LDCs. Journal of Business and Economics Statistics, 18(1), 10-17.

Asafu-Adjeye, J. (1999). Exchange rate volatility and export growth in Fiji. Asia Pacific School of Economics and 
Management Working Papers, 99.

Baak, S. (2004). Exchange rate volatility and trade among the Asian Pacific. International University of Japan, 26 April. Available at http://repec.org/esFEAM04/up.29293.1080736850.pdf.

Bahmani-Oskooee, M., \& Ardalani, Z. (2010). Exchange rate volatility and US commodity trade with the rest of world. International Review of Applied Economics, 24(5), 511-532. https://doi.org/10.1080/02692171.2010.483466

Bailey, M. J., \& Tavlas, G. (1987). The impact of exchange rate volatility on export growth: Some theoretical considerations and empirical results. Journal of Policy Modelling, 9, 205-243. https://doi.org/10.1016/0161-8938(87)90010-X

Bamba, I., \& Reed, M. (2004). Monetary policy impacts on cash crops coffee and cocoa using structural vector error correction model. Paper presented at the meeting of the American Agricultural Economist Association, August 1-4 2004, Denver, Colorado, US

Bini-Smaghi, L. (1991). Exchange rate variability and trade. Why is it so difficult to find any relationship? Applied Economics, 23, 927-936. https://doi.org/10.1080/00036849100000041

Bollerslev, T. (1986). Generalised autoregressive conditional heteroskedasticity. Journal of Econometrics, 31, 307-327. https://doi.org/10.1016/0304-4076(86)90063-1

Box, G., \& Jenkins, G. (1976). Time series analysis: Forecasting and control. San Franscisco: Holden Da.

Campa, J. (2004). Exchange rates and trade: How important is hysteresis in trade. European Economic Review, 48, 527-548. https://doi.org/10.1016/S0014-2921(02)00320-3

Chilowa, W. (1998). The impact of agricultural liberalisation of food security in Malawi. Food Policy, 23(6), 553-569. https://doi.org/10.1016/S0306-9192(98)00062-1

Chit, M. (2008). Exchange rate volatility and exports: Evidence from the ASEAN-China Free Trade Area. Journal of Chinese Economic and Business Studies, 6(3), 261-277. https://doi.org/10.1080/14765280802283543

Chowdhury, A. (1993). Does exchange rate volatility depress trade? Evidence from error-correction models. The Review of Economics and Statistics, 75(4), 700-706. https://doi.org/10.2307/2110025

De Grauwe, P. (1988). Exchange rate variability and the slowdown in the growth of international trade .IMF Staff Papers, 35, 63-84. https://doi.org/10.2307/3867277

Dickey, D., \& Fuller, W. (1979). The distribution of the estimation for autoregressive time series with a unit root. Journal of the American Statistical Association, 74, 427-431.

Doroodian, K. (1999). Does exchange rate volatility deter international trade in developing countries? Journal of Asian Economics, 10(3), 465-474. https://doi.org/10.1016/S1049-0078(99)00038-X

Enders, W. (2010). Applied Econometric Time Series, Third Edition, Massachutes, Wiley

Engle, R., \& Granger, C. (1987). Co-integratiion and error correction representation, estimation and testing. Econometrica, 55, 251-276. https://doi.org/10.2307/1913236

Erdem, E., \& Nazlioglu, S. (2010). Exchange rate uncertainty and agricultural trade: panel co-integration analysis for Turkey. Agricultural Economics, 41, 537-543. https://doi.org/10.1111/j.1574-0862.2010.00469.x

FAO (2010). Projections of tobacco production, consumption and trade. Food and Agriculture Organisation report. Available at: www.fao.org/DOCREP/006/Y4956E/Y4966E00.htm

Ghebrechristos, Y. E. (2004). The impact of exchange rate volatility on exports: a case study of South Africa's citrus fruit exports, MSc Agric Thesis. Department of Agricultural Economics, University of the Free State.

Gotur, P. (1985). Effects of exchange rate volatility on trade. IMF staff papers,32, 475-512. https://doi.org/10.2307/3866807

Granger, C., \& Lee, T. (1990). Multi-co-integration. Advances in Econometrics, 8, 77-84

Grube, B., \& Samanta, S. (2003). Effects of exchange rate uncertainty on Mexican foreign trade. The Multinational Business Review, 11(2), 3-15. https://doi.org/10.1108/1525383X200300008

Gujarati, D. N. (2003). Basic Econometrics. International Edition. New York: McGraw-Hill Higher Education

Harrigan, J. (1991). Malawi. In P. Mosley, J. Harrigan \& J. Toye. Aid and power: the World Bank and policy-based lending London, Routledge.

Hendry, D. (1987). Econometric methodology: A personal perspective. In Advances in Econometrics, Second edition, T. Bewley, Cambridge, UK.: Cambridge University Press. https://doi.org/10.1017/CCOL0521345529.002 
Jooste, A., Alemu, Z., Botha, E., \& Van Schalkwyk, H. (2003). Investigation into the supply chain of beef for the FPMC appointed by the Minister of Agriculture. Report for the Food Monitoring Price Committee.

Jordaan, H., Grove, B., Jooste, A., \& Alemu, G. (2007). Measuring the price volatility of certain field crops in South Africa using the ARCH/GARCH Approach. Agrekon, 46(3), 306-322. https://doi.org/10.1080/03031853.2007.9523774

Just, R., \& Pope, R. (2002). A comprehensive assessment of the role of risk in US agriculture. Boston: Kluwer Academic Publishers. https://doi.org/10.1007/978-1-4757-3583-3

Kandilov, I. (2008). The effects of exchange rate volatility on agricultural trade. American Journal of Agricultural Economics, 90, 1028-1043. https://doi.org/10.1111/j.1467-8276.2008.01167.x

Kasman, A., \& Kasman, A. (2005). Exchange rate uncertainty in Turkey and its impact on export volume. METU Studies in Development, 32, 41-58.

Khosa, J, Botha, I., \& Pretorius, I. (2015). The impact of exchange rate volatility on emerging markets exports. Independent Research Journal in the Management Sciences, 15(1), 257-266. https://doi.org/10.4102/ac.v15i1.257

Kwalingana, S., Simwaka, K., Munthali, T., \& Chiumia, A. (2012). The short-run and long-run trade balance response to exchange rate changes in Malawi. Journal of Development and Agricultural Economics, 4(8), 221-232. https://doi.org/10.5897/JDAE12.023

Leybourne, S., \& McCabe, B. (1994). A consistent test for a unit root. Journal of Business and Economics Statistics, 12(2), 157-166.

McKenzie, M. (1998). The impact of exchange rate volatility on Australian trade flows. Journal of International Financial Markets, Institutions and Money, 8, 21-38. https://doi.org/10.1016/S1042-4431(98)00022-5

McKenzie, M. (1999). The impact of the exchange rate volatility on international trade flows. Journal of Economic Surveys, 13(1), 71-76. https://doi.org/10.1111/1467-6419.00075

McKenzie, M., \& Brooks, R. (1997). The impact of exchange rate volatility on German-US trade flows. Journal of International Financial Markets, Institutions and Money, 7(1), 73-87. https://doi.org/10.1016/S1042-4431(97)00012-7

Mello, L. (2005). Estimating a fiscal reaction function: The case of debt sustainability in Brazil. ECO/WKP(2005), 10, 1-27. https://doi.org/10.1787/556325773018

Mello, L. (2005). Estimating a fiscal reaction function: The case of debt sustainability in Brazil. ECO/WKP(2005), 10, 1-27. https://doi.org/10.1787/556325773018

Mkwara, B. (2010). The impact of tobacco marketing and pricing policy reforms on income inequality amongst growers in Malawi. What lessons can be learnt from the Australian experience? The Australian Agricultural \& Resource Economic Society (AARES) conference paper, 2010.

Moledina, A., Roe, T., \& Shane, T. (2003). Measurement of commodity price volatility and welfare consequences of eliminating volatility. Working Paper at the Economic Development Centre, University of Minnesota

Monk, M. J., Jordaan, H., \& Grové, B. (2010). Factors affecting the price volatility of July futures contracts for white maize in South Africa. Agrekon, 49(4), 446-458. https://doi.org/10.1080/03031853.2010.526420

Mukhtar, T., \& Malik, J. (2010). Exchange rate volatility and export growth: Evidence from selected South Asian countries. SPOUDAI, 60(3), 58-68.

Mwasikakata, M. (2003). Tobacco: an economic lifeline? The case of tobacco farming in Kasungu Agricultural Development Division, Malawi, ILO Sector Activities Programme Working Paper No. 184, Geneva.

Ogundeji, A. (2010). Econometric estimation of Armington elasticities for selected agricultural products in South Africa. Unpublished Msc thesis, Department of Agricultural Economics, University of the Free State.

Orr, A. (2000). Green Gold?: Burley tobacco, smallholder agriculture and poverty alleviation in Malawi. World Development, 28(2), 347-363. https://doi.org/10.1016/S0305-750X(99)00127-8

Ozturk, I., \& Kalyoncu, H. (2009). Exchange rate volatility and trade: An empirical investigation from cross country investigation. African Development Review, 21(3), 499-513. https://doi.org/10.1111/j.1467-8268.2009.00220.x

Persuad, S., \& Meade, B. (2009). Trade and development: When exports lack diversification: A case study from Malawi.USDA Economic Research Service, 77, 1-4. https://doi.org/10.2139/ssrn.1452941

Poulton, C., Kydd, J., \& Kabame, D. (2007). Competitive commercial agriculture in Sub-Saharan Africa region: Case study on Malawi tobacco. Centre for Environmental Policy Working Paper, Imperial College, London 
RBM (2010). The evolution of the exchange rate determination in Malawi, Reserve Bank of Malawi Research papers

Silumbu, E. (1995). The role of exchange rate and monetary policy in the monetary approach to the balance of payments: Evidence from Malawi. AERC Research Paper, 37, 1-33

Situ, J. (2015). The impact of exchange rate volatility on exports to US.: A comparison between Developed and Export-oriented Less Developed Countries. International Journal of Business and Management, 10(5), 214-221. https://doi.org/10.5539/ijbm.v10n5p214

Tabar, M., \& Akbar, A. (2009). Agricultural export and exchange rate volatility in Iran's economy. International Conference on Applied Economics-IC0AE.

Tenreyro, S. (2007). On the trade impact of nominal exchange rate volatility. Journal of Development Economics, 82, 485-508. https://doi.org/10.1016/j.jdeveco.2006.03.007

Worako, T. K., Jordaan, H., \& Van Schalkwyk, H. D. (2011). Instigating volatility in coffee prices along the Ethiopian coffee value chain. Agrekon, 50(3), 90-108. https://doi.org/10.1080/03031853.2011.617865

World Bank. (1996). Accelerating Malawi's growth: Long term prospects and transitional problems, Southern Africa Department, Africa Region.

\section{Copyrights}

Copyright for this article is retained by the author(s), with first publication rights granted to the journal.

This is an open-access article distributed under the terms and conditions of the Creative Commons Attribution license which permits unrestricted use, distribution, and reproduction in any medium, provided the original work is properly cited. 